\title{
Toxicity and Sublethal Effects of Potassium Permanganate in Tambaqui (Colossoma macropomum)
}

\author{
André Luiz Ferreira da Silva, Edsandra Campos Chagas ${ }^{1}$, Levy Carvalho Gomes, Lucelle \\ Dantas de Araújo, Clichenner Rodrigues da Silva, and Franmir Rodrigues Brandão
}

Embrapa Western Amazon, Rodovia AM 010, Km 29, 69011-970 Manaus, AM, Brazil

Tambaqui (Colossoma macropomum) is a species that has shown promise in different intensive fish farming systems, including nurseries, streams, and cages (Merola and Souza 1988; Andrade et al. 1993; Chellapa et al. 1995; Arbeláez-Rojas et al. 2002).

The parasites most frequently found on tambaquis cultured in cages are monogeneans Anacanthorus spathulatus and Linguadactyloides brinkmanni (Varella et al. 2003). High infestations of these monogeneans on tambaqui gills can impede gas exchange on the surface of the gill lamellae (Thatcher 1981).

A therapeutic chemical widely used in fish production to control monogenean parasites is potassium permanganate $\left(\mathrm{KMnO}_{4}\right)$ (Kabata 1985). $\mathrm{KMnO}_{4}$, an oxidizing agent, has been used for many years to prevent gill parasites and bacterial and fungal infections (Kabata 1985; Scott 1993).

The toxicity of potassium permanganate has been determined for several fish species (Marking and Bills 1975; Tucker 1987; Bills et al. 1993), and several factors, including $\mathrm{pH}$, total alkalinity, total hardness, and chemical oxygen demand (COD), have been found to affect the toxicity of this chemical to fish (Tucker 1987; Straus 2004).

Marking and Bills (1975), Tucker (1987) and Straus (2004) suggested that the toxicity of $\mathrm{KMnO}_{4}$ to channel catfish (Ictalurus punctatus), rainbow trout (Oncorhynchus mykiss) and hybrid striped bass (Morone chrysops $\times$ M. saxatilis) is related to water hardness, $\mathrm{pH}$, and COD. Information about the physiological effects of exposure to sublethal concentrations of $\mathrm{KMnO}_{4}$ is, however, limited. For channel catfish, it has been observed that stress indicators (plasma cortisol, glucose, chloride, and osmolality) were modified

\footnotetext{
${ }^{1}$ Corresponding author.
}

when the fish was exposed to $2.19 \mathrm{mg} / \mathrm{L}$ concentrations of $\mathrm{KMnO}_{4}$ for $36 \mathrm{~h}$ (Griffin et al. 2002). Such information is important to assist in evaluating the risks of using this chemical to treat parasitic diseases in tambaquis.

The objective of this study is to determine the toxicity of potassium permanganate in tambaquis (C. macropomum) and to find out some toxic effects of its sublethal concentrations by analyzing physiological parameters.

\section{Materials and Methods}

Tambaqui juveniles (standard length of $11.80 \pm$ $0.05 \mathrm{~cm}$ and weight of $59.10 \pm 1.34 \mathrm{~g}$; average $\pm \mathrm{SE}$ ) were acquired from Santo Antônio farm (Rio Preto da Eva, AM, Brazil). The fish were immediately transported to the experimental site of Embrapa Western Amazon, where they were acclimatized in ponds of $200 \mathrm{~m}^{3}$. The fish were fed with commercial tambaqui feed $(36 \%$ of crude protein) until satiation, $6 \mathrm{~d}$ a week, during the preexperimental period. The feeding of animals was suspended $24 \mathrm{~h}$ before and during the toxicity tests.

Glass aquaria containing $40 \mathrm{~L}$ of water under semistatic conditions and constant aeration were used for the tests. The tests were carried out with three replicated group of six animals for each treatment, using a completely random design. After a 24-h acclimatization period, the groups of fish were exposed to $0,6.5,7.0,8.0,9.0,10.0,11.5$, and $13.0 \mathrm{mg} / \mathrm{L}$ of $\mathrm{KMnO}_{4}$ (concentrations chosen based on preliminary tests).

The physiochemical parameters of water in the aquariums were monitored during the toxicity tests. The $\mathrm{pH}$ values $(7.16 \pm 0.44)$ were obtained using a $\mathrm{pH}$ meter YSI Environmental Model pH100 (Yellow Springs Instrument Co., Yellow Springs, OH, USA). Temperature (26.70 \pm $0.11 \mathrm{C})$ and dissolved oxygen $(7.09 \pm 0.07 \mathrm{mg} / \mathrm{L})$ 
were taken using a YSI Model 55 portable oxygen meter (Yellow Springs Instrument Co.). Total alkalinity $\left(10.63 \pm 1.60 \mathrm{mg} / \mathrm{L} \mathrm{CaCO}_{3}\right)$ and total hardness $\left(15.68 \pm 1.20 \mathrm{mg} / \mathrm{L} \mathrm{CaCO}_{3}\right)$ were determined by titration. Total ammonia $(0.98 \pm 0.19 \mathrm{mg} / \mathrm{L})$ was determined by endophenol method (APHA 1989) and the biochemical oxygen demand $(8.40 \pm 2.81 \mathrm{mg} / \mathrm{L})$ by 5d-BOD method (APHA 1989). The COD $(8.46 \pm 2.82 \mathrm{mg} / \mathrm{L})$ followed the procedures described by APHA (1989) with the proposed modification of Boyd and Tucker (1992).

Experiments for exposure to sublethal concentrations of $\mathrm{KMnO}_{4}$ were carried out for $96 \mathrm{~h}$ with three replicated groups of six fish (standard length of $11.68 \pm 0.05 \mathrm{~cm}$ and weight of $52.27 \pm 1.01 \mathrm{~g}$; average $\pm \mathrm{SE}$ ) for each aquarium treated at 0 and $4.30 \mathrm{mg} / \mathrm{L} \mathrm{KMnO}_{4}$ ( $50 \%$ of the lethal concentration; $\mathrm{LC}_{50}$ ). Three water parameters were measured: $\mathrm{pH}$, $7.39 \pm 0.07$; temperature, $25.67 \pm 0.13 \mathrm{C}$; and dissolved oxygen, $7.66 \pm 0.11 \mathrm{mg} / \mathrm{L}$.

Fish were anesthetized $(100 \mathrm{mg} / \mathrm{L}$ benzocaine; Gomes et al. 2001) and blood collected from the caudal vein of each of the six fish in the replications. The hematocrit $(\mathrm{Ht})$, using the method of Goldenfarb et al. (1971), and hemoglobin concentration $(\mathrm{Hb})$ following the cyanmethemoglobin method (Kampen and Zijlstra 1964) were determined, and red blood cells (RBCs) were counted under the light microscope using a Neubauer hemocytometer after blood dilution with formol citrate. Hematimetric equations (Acerete et al. 2004) were used to determine the mean corpuscular volume (MCV), the mean corpuscular hemoglobin $(\mathrm{MCH})$, and the mean corpuscular hemoglobin concentration (MCHC). Glucose levels were measured with a blood glucose monitor (Advantage ${ }^{\mathrm{TM}}$; Boehringer Mannheim GmbH, Mannheim, Germany). Plasma chloride levels were determined using a commercially available kit (colorimetric chloride; Doles ${ }^{\circledR}$, Goiás, Brazil), and a flame photometer (Micronal model B462) was used to determine sodium $\left(\mathrm{Na}^{+}\right)$and potassium $\left(\mathrm{K}^{+}\right)$levels.

The $\mathrm{LC}_{50}$ value of $\mathrm{KMnO}_{4}$ was determined by the Trimmed Spearman-Karber method (Hamilton et al. 1977), using the mean mortality of the fish. Results were expressed as mean \pm
SEM. Significant differences among means from physiological parameters of control versus animals exposed to sublethal concentrations of $\mathrm{KMnO}_{4}$ were established by Student's $t$ test $(P<0.05)$ (Zar 1999).

\section{Results and Discussion}

Mortality rates in tambaquis were directly related to higher concentrations of $\mathrm{KMnO}_{4}$ in the water (Fig. 1). The higher mortality rates occurred within $24 \mathrm{~h}$ with few changes after $24 \mathrm{~h}$, which conform to the findings of Marking and Bills (1975). The tambaquis exposed to concentrations above $6.5 \mathrm{mg} \mathrm{KMnO}_{4} / \mathrm{L}$ became agitated in the first hours of exposure to the chemical, with an intense mucus excretion and alterations in the opercular movements. After $24 \mathrm{~h}$ of exposure, the tambaquis showed signs of lethargy and loss of equilibrium. The same changes in behavior were observed by Straus (2004) for hybrid striped bass (Morone chrysops $\times$ Morone saxatilis) exposed to $\mathrm{KMnO}_{4}$ for $24 \mathrm{~h}$.

$\mathrm{LC}_{50}-96 \mathrm{~h}$ of $\mathrm{KMnO}_{4}$ for tambaquis was calculated to be $8.60 \mathrm{mg} / \mathrm{L}$ (Fig. 1). This value indicated that the tambaqui is more tolerant of $\mathrm{KMnO}_{4}$ than channel catfish (I. punctatus), striped bass (M. saxatilis), common carp (Cyprinus carpio), and American eel (Anguilla rostrata) $\left(\mathrm{LC}_{50}-96 \mathrm{~h}\right.$ of $\mathrm{KMnO}_{4}$ were $4.5,4.0$, 3.05, and $7.52 \mathrm{mg} / \mathrm{L}$, respectively) (Hughes 1971; Hilton and Eversole 1980; Tucker 1987; Das and Kaviraj 1994).

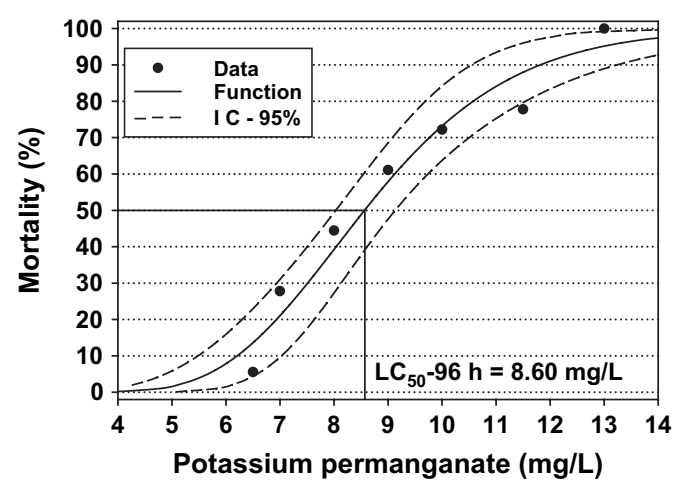

FIGURE 1. The effect of potassium permanganate concentration on the mortality of Colossoma macropomum in $96 \mathrm{~h}$. 
TABLE 1. Physiological parameters of tambaqui, Colossoma macropomum, after exposure to sublethal concentration of $\mathrm{KMnO}_{4}$ for $96 \mathrm{~h}$.

\begin{tabular}{lcc}
\hline & \multicolumn{2}{c}{ Potassium permanganate concentration } \\
\cline { 2 - 3 } Parameters & $0 \mathrm{mg} / \mathrm{L}$ & $4.30 \mathrm{mg} / \mathrm{L}$ \\
\hline $\mathrm{Ht}(\%)$ & $31.89 \pm 1.15$ & $31.92 \pm 1.71$ \\
$\mathrm{Hb}(\mathrm{g} / \mathrm{dL})$ & $8.65 \pm 0.23$ & $8.76 \pm 0.31$ \\
$\mathrm{RBC}\left(10^{6} / \mathrm{mm}^{3}\right)$ & $1.74 \pm 0.12$ & $1.75 \pm 0.08$ \\
$\mathrm{MCV}\left(\mu \mathrm{m}^{3}\right)$ & $161.49 \pm 17.93$ & $150.13 \pm 12.96$ \\
$\mathrm{MCH}(\mathrm{pg})$ & $49.73 \pm 3.58$ & $52.61 \pm 2.84$ \\
$\mathrm{MCHC}(\%)$ & $27.50 \pm 0.86$ & $27.98 \pm 0.72$ \\
Glucose $(\mathrm{mg} / \mathrm{dL})$ & $50.90 \pm 3.90$ & $63.50 \pm 3.44^{*}$ \\
Chloride $(\mathrm{mmol} / \mathrm{L})$ & $117.24 \pm 4.81$ & $136.11 \pm 4.00^{*}$ \\
Sodium $(\mathrm{meq} / \mathrm{L})$ & $126.92 \pm 2.56$ & $136.10 \pm 2.54^{*}$ \\
Potassium $(\mathrm{meq} / \mathrm{L})$ & $5.48 \pm 0.32$ & $4.89 \pm 0.36$ \\
\hline
\end{tabular}

$\mathrm{Ht}=$ hematocrit; $\mathrm{hb}=$ hemoglobin concentration; $\mathrm{RBC}=$ red blood cell; $\mathrm{MCV}=$ mean corpuscular volume; $\mathrm{MCH}=$ mean corpuscular hemoglobin; $\mathrm{MCHC}=$ mean corpuscular hemoglobin concentration. Values are means $( \pm$ SEM $)$ of six fish of each aquarium. Means followed by asterisks are significantly different at $P<0.05$ by Student's $t$ test.

For tambaquis, significant alterations were not observed in the $\mathrm{Ht}, \mathrm{Hb}, \mathrm{RBC}, \mathrm{MCV}, \mathrm{MCH}$, and MCHC values after $96 \mathrm{~h}$ of exposure to the sublethal concentrations $(4.30 \mathrm{mg} / \mathrm{L})$ of $\mathrm{KMnO}_{4}$ (Table 1). However, a significant increase in glucose, chloride, and plasmatic sodium levels was observed in tambaquis exposed to $4.30 \mathrm{mg} / \mathrm{L}$ of $\mathrm{KMnO}_{4}$ (Table 1); a decrease in the plasmatic potassium values, although not significant, was also observed for fish exposure to $\mathrm{KMnO}_{4}$ (Table 1). Griffin et al. (2002) found changes in the glucose and plasmatic chloride levels in channel catfish exposed for $36 \mathrm{~h}$ to $2.19 \mathrm{mg} / \mathrm{L}$ of $\mathrm{KMnO}_{4}$, which suggests a disturbance in the ionic balance of both species.

Potassium-permanganate-treated tambaquis showed moderate increases in the secondary stress indicators: glucose, $\mathrm{Na}^{+}$, and $\mathrm{Cl}^{-}$and a decrease in $\mathrm{K}^{+}$. Hyperglycemia in fish under stress conditions results from the rapid mobilization of energy reserves, which makes it possible for the animal to survive through the period of disturbance (Morgan and Iwama 1997). According to Mazeaud and Mazeaud (1981), disturbances in concentrations of $\mathrm{Na}^{+}$and $\mathrm{Cl}-$, in stress situations, result from increased adrenaline level in the blood.

It is important to determine the toxicity of $\mathrm{KMnO}_{4}$ in tambaquis and establish the tolerance limits on using this chemical because $2-5 \mathrm{mg} / \mathrm{L}$ long baths are frequently used to treat parasitic diseases in fish (Kabata 1985; Scott 1993). The results of the present study show that a sublethal concentration of $\mathrm{KMnO}_{4}(4.30 \mathrm{mg} / \mathrm{L}) \mathrm{ac}-$ tivates some secondary indications of stress, provoking alterations in the homeostasis of the tambaquis. Exposure of up to $4.30 \mathrm{mg} / \mathrm{L}$ of $\mathrm{KMnO}_{4}$ may have much more deleterious effects on the fish.

\section{Acknowledgments}

This study was supported by the "TANRE/ FINEP/FUCAPI" and "Tanque-rede BASA" Projects. The authors are thankful to José Pereira and Márcia Pessoa, from Embrapa Western Amazon, for their assistance in the experiments and water quality analyses. We also thank M. V. Garcia for design of graphics. A. L. F. d. S., L. D. d. A., C. R. S., and F. R. B. are recipients of student fellowship from the National Council for Scientific and Technological Development $(\mathrm{CNPq})$ and Fundação de Amparo à Pesquisa do Estado do Amazonas (FAPEAM).

\section{Literature Cited}

Acerete, L., J. C. Balasch, E. Espinosa, A. Josa, and L. Tort. 2004. Physiological responses in Eurasian perch (Perca fluviatilis, L.) subjected to stress by transport and handling. Aquaculture 237:167-178.

Andrade, P. C. M., A. S. Tolentino, and C. E. C. Freitas. 1993. Desenvolvimento de juvenis de tambaqui (Colossoma macropomum Cuvier, 1818) em gaiolas. Revista da Universidade do Amazonas 2:21-30. 
APHA (American Public Health Association, American Water Works Association, and Water Pollution Control Federation). 1989. Standard methods for the examination of water and wastewater, 17th edition. American Public Health Association, Washington, DC, USA.

Arbeláez-Rojas, G. A., D. M. Fracalossi, and J. D. I. Fim. 2002. Composição corporal de tambaqui, Colossoma macropomum, e matrinxã, Brycon cephalus, em sistemas de cultivo intensivo, em igarapé, e semiintensivo, em viveiros. Revista Brasileira de Zootecnia 31:1059-1069.

Bills, T. D., L. L. Marking, and G. E. Howe. 1993. Sensitivity of juvenile striped bass to chemicals used in aquaculture. Resource publication 192, U.S. Department of Interior, Fish and Wildlife Service, Washington, DC, USA.

Boyd, C. E. and C. S. Tucker. 1992. Water quality and pond soil analyses for aquaculture. Alabama Agricultural Experiment Station, Auburn University, Alabama, USA.

Chellapa, S., N. T. Chellapa, W. T. Barbosa, F. A. Huntigord, and M. C. M. Beveridge. 1995. Growth and production of the Amazonian tambaqui in fixed cages under different feeding regimes. Aquaculture International 3:11-21.

Das, B. K. and A. Kaviraj. 1994. Individual and interactive lethal toxicity of cadmium, potassium permanganate and cobalt chloride to fish, worm and plankton. Geobios 21:223-227.

Goldenfarb, P. B., F. P. Bowyer, T. Hall, and E. Brosious. 1971. Reproducibility in the hematology laboratory: the microhematocrit determination. American Journal of Clinical Pathology 56:35-36.

Gomes, L. C., A. R. Chippari-Gomes, N. P. Lopes, R. Roubach, and C. A. R. M. Araújo-Lima. 2001. Efficacy of benzocaine as an anesthetic in juvenile tambaqui, Colossoma macropomum. Journal of the World Aquaculture Society 32:426-431.

Griffin, B. R., K. B. Davis, A. Darwish, and D. L. Straus. 2002. Effect of exposure to potassium permanganate on stress indicators in channel catfish Ictalurus punctatus. Journal of the World Aquaculture Society 33:1-9.

Hamilton, M. A., R. C. Russo, and R. V. Thurston. 1977. Trimmed Spearman-Karber method for estimating median lethal concentration in toxicity bioassays. Environmental Science and Technology 11:714-719.

Hilton, M. J. and A. G. Eversole. 1980. Toxicity and tolerance studies with yellow-phase eels: five chemicals. Progressive Fish-culturist 42:201-203.
Hughes, J. S. 1971. Tolerance of striped bass, Morone saxatilis (Walbaum), larvae and fingerlings to nine chemicals used in pond culture. Proceedings of the 24th Annual Conference, Southeastern Association of Game and Fish Commissioners 24:431-438.

Kabata, Z. 1985. Parasites and diseases of fish cultured in the tropics. Taylor \& Francis, Ltd., Basingtsoke, UK.

Kampen, E. J. and W. G. Zijlstra. 1964. Erythrocytometric methods and their standardization. Clinica Chimica Acta 6:538-542.

Marking, L. L. and T. D. Bills. 1975. Toxicity of potassium permanganate to fish and its effectiveness for detoxifying antimycin. Transactions of the American Fisheries Society 104:579-784.

Mazeaud, M. and F. Mazeaud. 1981. Adrenergic responses to stress in fish. Pages 49-75 in A. D. Pickering, editor. Stress and fish. Academic Press, New York, New York, USA.

Merola, N. and J. H. Souza. 1988. Cage culture of the Amazon fish tambaqui, Colossoma macropomum, at two stocking densities. Aquaculture 11:15-21.

Morgan, J. D. and G. K. Iwama. 1997. Measurements of stressed states in the field. Pages 247-268 in G. K. Iwama, A. D. Pickering, J. P. Sumpter, and C. B. Schreck, editors. Fish stress and health in aquaculture. Society for Experimental Biology Seminar Series 62. University Press, Cambridge, UK.

Scott, P. 1993. Therapy in aquaculture. Pages 131-152 in L. Brown, editor. Aquaculture for veterinarians: fish husbandry and medicine. Pergamon Press, Oxford, UK.

Straus, D. L. 2004. Comparison of the acute toxicity of potassium permanganate to hybrid striped bass in well water and diluted well water. Journal of the World Aquaculture Society 35:55-60.

Thatcher, V. E. 1981. Patologia de peixes da Amazônia Brasileira. 1. Aspectos gerais. Acta Amazônica 11: 125-140.

Tucker, C. S. 1987. Acute toxicity of potassium permanganate to channel catfish fingerlings. Aquaculture 60:93-98.

Varella, A. M. B., S. N. Peiro, J. C. O. Malta, and J. N. P. Lourenço. 2003. Monitoramento da parasitofauna de Colossoma macropomum (Cuvier, 1818) (Osteichthyes: Characidae) cultivado em tanques-rede em um lago de várzea na Amazônia, Brasil. Pages 95-106 in E. C. Urbinati and J. E. P. Cyrino, editors. XII Simpósio Brasileiro de Aqüicultura. Aquabio, Jaboticabal, São Paulo, Brasil.

Zar, J. H. 1999. Biostatistical analysis. Prentice Hall, Upper Saddle River, New Jersey, USA. 